\title{
Additional Artifact Collections from the Gardener Site (41CP55), Camp County, Texas
}

Timothy K. Perttula

Heritage Research Center, Stephen F. Austin State University

Bo Nelson

Heritage Research Center, Stephen F. Austin State University

Follow this and additional works at: https://scholarworks.sfasu.edu/ita

Part of the American Material Culture Commons, Archaeological Anthropology Commons, Environmental Studies Commons, Other American Studies Commons, Other Arts and Humanities Commons, Other History of Art, Architecture, and Archaeology Commons, and the United States History Commons

Tell us how this article helped you.

This Article is brought to you for free and open access by the Center for Regional Heritage Research at SFA ScholarWorks. It has been accepted for inclusion in Index of Texas Archaeology: Open Access Gray Literature from the Lone Star State by an authorized editor of SFA ScholarWorks. For more information, please contact cdsscholarworks@sfasu.edu. 


\section{Additional Artifact Collections from the Gardener Site (41CP55), Camp County,}

Texas

\section{Creative Commons License}

\section{(c) (1) (8)}

This work is licensed under a Creative Commons Attribution-NonCommercial 4.0 International License 


\title{
Additional Artifact Collections from the Gardener Site (41CP55), Camp County, Texas
}

\author{
Timothy K. Perttula and Bo Nelson
}

\section{INTRODUCTION}

The Gardener site (41CP55) was first recorded by Sullivan (1977) prior to construction of Lake Bob Sandlin on Big Cypress Creek. A surface collection of sherds and daub suggested that the site was the locus of a Late Caddo period (ca. A.D. 1450-1680) settlement and burned house (see Thurmond 1990:56). However, no further archaeological work was done at the site before it was inundated by Lake Bob Sandlin in the late 1970s.

Recently, because of lower flood pool levels (about $9 \mathrm{ft}$. below normal flood pool) at Lake Bob Sandlin due to East Texas drought conditions, archaeological materials from the Gardener site have been exposed along the shoreline of the lake. Perttula et al. (2014) documented a substantial aboriginal artifact assemblage collected from the shoreline surface of the site, and this article documents a second collection of artifacts from the Gardener site.

The Gardener site, whose overall extent is not known (see Thurmond 1990:56), is located along an upland slope (330 ft. amsl) on the west side of Picket Spring Branch, a small and northward-flowing tributary to Big Cypress Creek, in the Post Oak Savanna. The old channel of Big Cypress Creek lies approximately $1.8 \mathrm{~km}$ north of the site.

\section{ARTIFACT ASSEMBLAGE}

This second artifact collection from the Gardener site includes both lithic and ceramic artifacts. The chipped stone assemblage is comprised of four arrow points, two dart points, a dart point preform, seven biface fragments, a unifacial flake tool, and a gouge fragment; there also is a cache of four bifaces/gouges found at the site. There are 178 pieces of lithic debris in this collection.

The assemblage of Caddo ceramic vessel sherds in this second collection totals 93 sherds. This includes 28 plain rim, body, and base sherds and 65 decorated rim and body sherds from both utility ware and fine ware vessels.

There also are seven well-preserved pieces of daub from a buried ancestral Caddo house at the site, along with a single piece of quartzite fire-cracked rock.

\section{Chipped Stone Tools}

The arrow points in this collection, all made from heat-treated local quartzite, are from the Late Caddo, Titus phase occupation. They include two Maud arrow points, an ovoid arrow point preform, and a blade fragment. The Maud points are consistent with the typologically identifiable arrow points $(n=12)$ from the first collection (Perttula et al. 2014) in that they are exclusively post-A.D. 1550 Titus phase styles, Maud, Talco, and Bassett forms. 


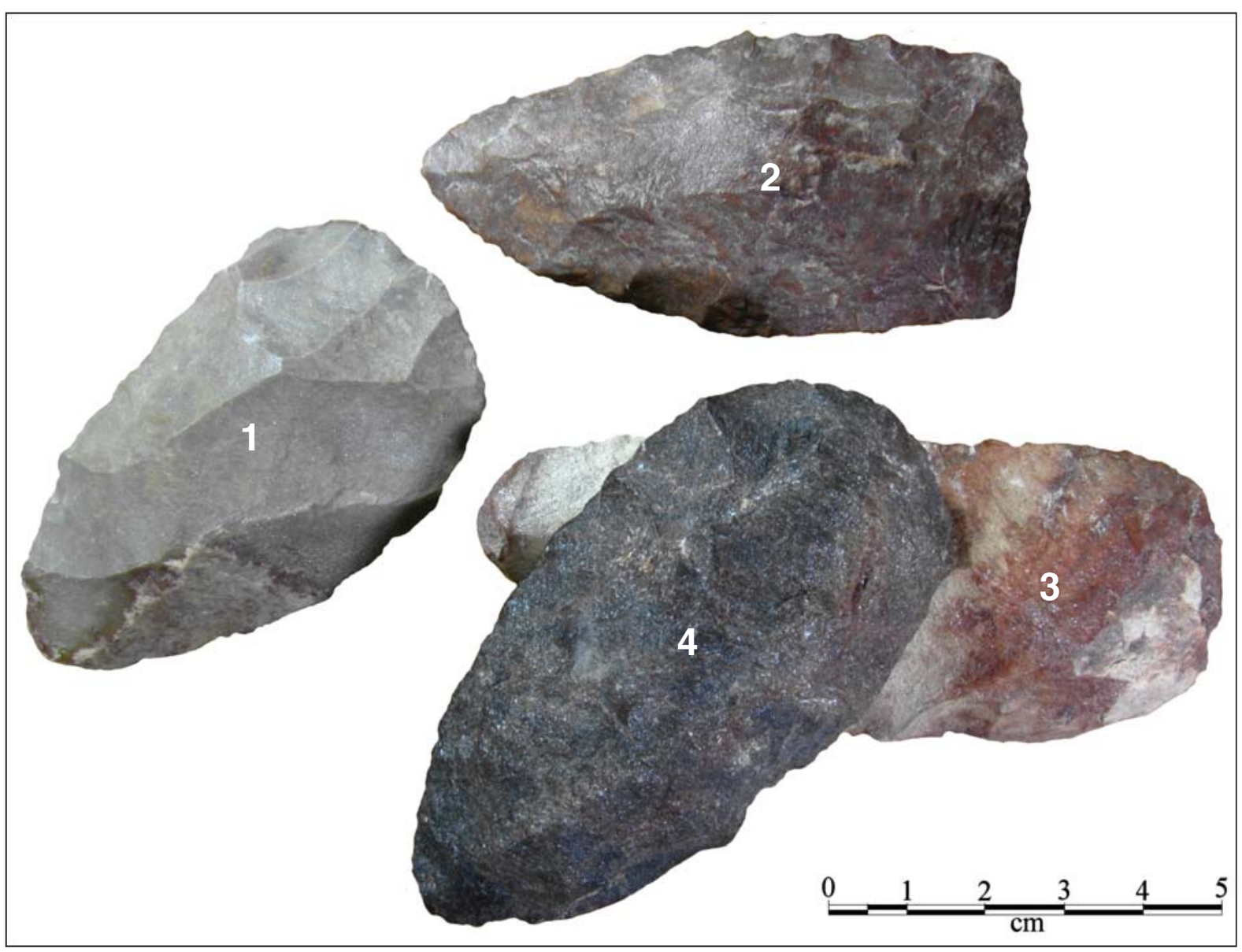

Figure 1. The cache of four chipped stone bifaces and gouges from the Gardener site, as found at the site.

The other chipped stone tools in the second collection from the Gardener site are from the use of the site during the Late Archaic and Woodland periods. They include a Gary, var. Camden dart point made from local petrified wood, a Williams dart point from quartzite, and a quartzite dart point preform. There are also seven biface fragments (made from heat-treated quartzite) and a unifacial flake tool (heat-treated quartzite). There is also a hematite gouge fragment in this collection; it has no remnants of polishing wear, and has been broken above the working edge.

A cache of four bifaces and chipped stone gouges was identified eroding out of the clay B-horizon along the now exposed shoreline. The cache covers a $12.6 \times 8.6 \mathrm{~cm}$ area, with the tools closely nestled together, one of the bifaces (No. 4) resting above the large biface (No. 3 on Figure 1).

Artifacts 1 and 2 (Figure 2a-b) are gouges with unifacial working edges. Both are made from local quartzite, and they range from $63-71 \mathrm{~mm}$ in length, 35.6-38.0 mm in width, and 17.0-19.2 $\mathrm{mm}$ in thickness. Artifact 3 is a heat-treated quartzite bifacial knive with lateral use wear; it is $88 \mathrm{~mm}$ in length, $35 \mathrm{~mm}$ in width, and $16.9 \mathrm{~mm}$ in thickness (Figure 2c). Artifact 4 in the cache is a ferruginous sandstone biface found overlying part of Artifact 3 (see Figure 1). The ferruginous sandstone biface is $71 \mathrm{~mm}$ in length, $36 \mathrm{~mm}$ in width, and $18.0 \mathrm{~mm}$ in thickness; there is no use wear evidence on the biface. 


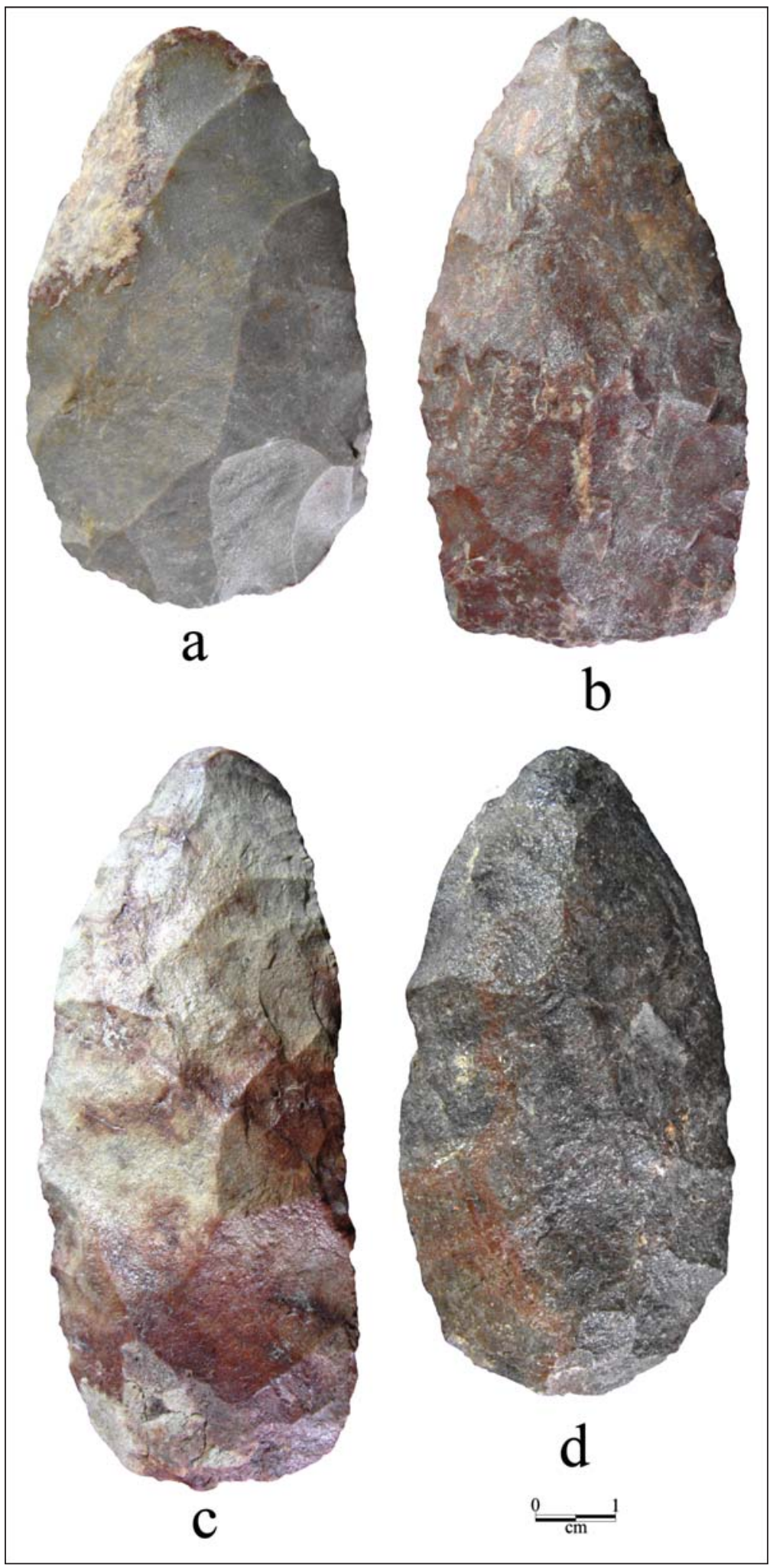

Figure 2. Artifacts 1-4 in the cache at the Gardener site: a, Artifact 1; b, Artifact 2; c, Artifact 3; d, Artifact 4. 


\section{LITHIC DEBRIS}

The lithic debris $(\mathrm{n}=178)$ in this second collection is almost exclusively from the manufacture of chipped stone tools with local quartzite raw materials. Quartzite lithic debris accounts for $96.1 \%(n=171)$ of the lithic debris, and $73 \%$ of this debris has stream-rolled cortical remnants. The other lithic raw materials represented in the lithic debris includes petrified wood $(n=2,1.1 \%$, both pieces are cortical), chalcedony $(n=1,0.6 \%$, cortical), grayish-yellow chert ( $\mathrm{n}=1,0.6 \%$, non-cortical), and gray chert ( $\mathrm{n}=3,1.7 \%, 33 \%$ cortical).

The percentage of lithic debris in this second collection as a whole with cortical remnants is a substantial $72.5 \%$, almost all of it from local lithic raw materials. This suggests that much of the knapping done at the Gardener site is a product of the reduction of pebble-sized pieces of local raw material gathered in nearby stream gravels, probably to obtain flakes of suitable size for chipped stone tool manufacture.

\section{CERAMIC SHERDS}

Only $2.2 \%$ of the plain and decorated sherds in this second collection of ceramic sherds from the Gardener site are bone-tempered; the remainder are from grog-tempered vessels. This proportion of bonetempered sherds is comparable to that documented in the first and larger sherd assemblage (Perttula et al. 2014). The plain sherds include one rim (with a direct rim and a flat lip), 26 body sherds, and one base sherd.

There are 65 decorated sherds in the second collection from the Gardener site. As with the earlier collection, both utility wares $(n=51)$ and fine wares $(n=14)$ are well represented in the Gardener site vessel ceramics. The utility wares comprise $78 \%$ of the decorated sherds.

The utility wares in the second collection are sherds primarily with brushed decorations: parallel brushed $(n=33)$, parallel brushed-incised $(n=6)$, opposed brushed $(n=1)$, and one lower rim-body sherd with horizontal brushing on the rim and vertical brushing on the vessel body (Figure 3a). These are probably from Bullard Brushed jars.

Other utility ware body sherds have parallel or straight appliqued ridges $(n=3)$ and vertical appliqued fillets $(n=1)$. Three other body sherds have straight incised lines and a fourth body sherd has cross-hatched incised lines, and there are two neck banded sherds from La Rue Neck Banded jars.

The engraved sherds in this collection include three rims and 11 body sherds. These fine ware sherds are probably all from Ripley Engraved vessels (see Perttula et al. 2012:Figure 5a-k; Suhm and Jelks 1962:Plates 64-65; Thurmond 1990:Figure 6), mostly from carinated bowls (see Figure 3b-h) and a compound bowl rim with widely-spaced horizontal engraved lines (see Figure 3i). These sherds have circle elements, slanting scroll elements, and scroll fill zones. Lastly, there are three body sherds with a single straight line, another with parallel engraved lines, and a fifth from a carinated bowl with a single horizontal engraved line above the carination.

There are 397 decorated rim and body sherds in the two collections from the Gardener site (Table 1). Among the utility wares are the types Bullard Brushed, Maydelle Incised, and Pease Brushed-Incised, as well as rim punctated, appliqued, and neck banded vessels. Approximately $83 \%$ of the decorated sherds are from utility wares, principally sherds from vessels with brushed (78\% of the utility wares and $65 \%$ of all the decorated sherds) decorations, with lesser amounts of incised (9.4\% of the utility wares, but $42 \%$ of the utility ware rims), appliqued (3.6\% of the utility wares), and punctated (3.6\% of the utility wares) decorations.

The fine wares sherds (17\% of the decorated sherds in the two collections, see Table 1) are from Ripley Engraved and Taylor Engraved vessels, including carinated bowls, compound bowls, and bottles. The principal motifs in the Ripley Engraved fine wares are scrolls and scroll and circles. 




Figure 3. A sample of decorated sherd design elements from the Gardener site: a, horizontalvertical brushed; b, engraved circle element; c, cross-hatched engraved bracket; d, vertical columns and an excised punctate; e, engraved slanting scroll fill zone; f, engraved circle element; g, engraved slanting scroll element; $h$, horizontal and vertical engraved lines; i, widely-spaced horizontal engraved lines. 
Table 1. Decorated sherds from the two collections at the Gardener site.

\begin{tabular}{lrrr}
\hline Decorative Method & Rim & Body & N \\
\hline Utility Ware & & & 12 \\
& - & 12 & 1 \\
Appliqued & - & 1 & 257 \\
Appliqued-incised & 5 & 252 & 14 \\
Brushed & 2 & 12 & 1 \\
Brushed-incised & - & 20 & 31 \\
Brushed-punctated & 11 & 2 & 2 \\
Incised & - & 4 & 12 \\
Neck banded & - & 305 & 331 \\
Neck banded-brushed & 8 & & 66 \\
Punctated & 26 & & 397 \\
Subtotal & & 50 & \\
Fine Ware & & 355 & \\
Engraved & 16 & & \\
\hline Totals & 42 & & \\
\hline
\end{tabular}

\section{SUMMARY AND CONCLUSIONS}

The Gardener site is located on a tributary to Big Cypress Creek in Lake Bob Sandlin in the Post Oak Savanna of East Texas. It is a multi-component site with evidence of its first use during the Late Archaic and Woodland periods by relatively mobile hunter-gatherers, but with a substantial Late Caddo period, Titus phase settlement. The Titus phase artifact assemblage from the site has several kinds of Late Caddo style arrow points (most notably Maud points), many pieces of daub from a burned Caddo house structure, and sherds from plain ware, utility ware, and fine ware ceramic vessels. The occurrence of Maud arrow points along with Ripley Engraved and Taylor Engraved fine wares suggests the Titus phase component at the Gardener site was a farmstead that was occupied ca. A.D. 1550.

\section{ACKNOWLEDGMENTS}

Lance Trask prepared the figures for this article.

\section{REFERENCES CITED}

Perttula, T. K., B. Nelson, and M. Walters

2012 Caddo Archaeology at the Henry Spencer Site (41UR315) in the Little Cypress Creek Basin of East Texas. Special Publication No. 20. Friends of Northeast Texas Archaeology, Pittsburg and Austin.

Perttula, T. K., B. Nelson, and R. Z. Selden, Jr.

2014 The Gardener Site (41CP55): A Late Caddo Settlement on Big Cypress Creek in East Texas. Journal of Northeast Texas Archaeology 44:1-11. 
Suhm, D. A. and E. B. Jelks (editors)

1962 Handbook of Texas Archeology: Type Descriptions. Special Publication No. 1, Texas Archeological Society, and Bulletin No. 4, Texas Memorial Museum, Austin.

Sullivan, T. L.

1977 Archaeological Investigations at Lake Bob Sandlin, Texas. Research Report No. 99. Archaeology Research Program, Southern Methodist University, Dallas.

Thurmond, J. P.

1990 Archeology of the Cypress Creek Drainage Basin, Northeastern Texas and Northwestern Louisiana. Studies in Archeology 5. Texas Archeological Research Laboratory, The University of Texas at Austin. 